\title{
Knowledge and quality as the factors of the business operations and competitiveness promotion - research results from Serbia
}

\author{
Article history: \\ Received: 28 February 2015 \\ Sent for revision: 18 March 2015 \\ Received in revised form: 24 May 2015 \\ Accepted: 26 May 2015 \\ Available online: 2 July 2015
}

\begin{abstract}
The paper deals with the analysis of knowledge and quality as key factors of the promotion of business operations and competitiveness promotion. The objective of this paper is to establish the relations between the quality and the level of business operation and competitiveness, and the relations between the investment in knowledge, training and professional development and the promotion of business operations quality. The paper presents the research conducted among the company managers in Serbia, where their attitudes and opinions were used for assessing the level of business operations and competitiveness, the company's readiness to invest in knowledge, training and professional development and quality promotion. The correlation analysis established the importance of the impacts of the given variables, where it was ascertained that promotion of the quality aspects has the greatest significance for the improvement of the competitive capacities of the Serbian companies. The importance of the research is evidenced in the results that can serve to Serbian company managers as the guidelines for the promotion of the business operations and competitiveness promotion.
\end{abstract}

Keywords: knowledge, quality, business operations promotion, competitiveness.

\footnotetext{
${ }^{1}$ Technical Faculty Mihajlo Pupin,Serbia, cvjetkovicm@gmail.com
} 
Cvjetković M.: Knowledge and quality as the factors of the business operations...

\title{
Znanje i kvalitet kao faktori unapređenja poslovanja i konkurentnosti - rezultati istraživanja iz Srbije
}

\begin{abstract}
Apstrakt: Rad se bavi analizom znanja i kvaliteta kao ključnih faktora unapređenja poslovanja i konkurentnosti. Cilj rada je da se utvrde relacije između kvaliteta na nivo poslovanja i konkurentnosti i relacije između ulaganja u znanje, obuku i razvoj zaposlenih na unapređenje kvaliteta poslovanja. $U$ radu je prikazano istraživanje sprovedeno među rukovodiocima preduzeća $u$ Srbiji, gde se na osnovu njihovih stavova i mišljenja ocenio nivo poslovanja $i$ konkurentnosti, spremnost preduzeća da ulaže u znanje, značaj obuke i razvoja zposlenih i unapređenja kvaliteta. Korelacionom analizom utvrđeni su međusobni odnosi posmatranih varijabli. Regresionim modelom utvrđen je značaj uticaja datih varijabli, gde je utvrđeno da najveći značaj na poboljšanje konkurentske sposobnosti srpskih preduzeća ima unapređenje aspekata kvaliteta. Značaj istraživanja se ogleda u rezultatima koji mogu poslužiti menadžerima preduzeća u Srbiji, kao smernice za unapređenja poslovanja i konkurentnosti.
\end{abstract}

Ključne reči: znanje, kvalitet, unapređenje poslovanja, konkurentnost.

\section{Introduction}

The paper presents the research that analyzes the impact of knowledge and quality aspects on the promotion of business operations and competitiveness of Serbian companies, and their mutual relations. Knowledge was always at the heart of the economic growth (Kahin and Foray, 2006). The importance of knowledge, as the key factor of competitiveness is increasing. The new paradigm of the human resources management is focused on creation of the corporative, productive, flexible and innovative working environment, which acknowledges the human resources value in the weighing of the buyers' needs and realization of the strategic business goals (Bhat, 2010). The research is aimed at ascertaining how much companies comprehend the importance of this resource, how much they care for the development of their employees and promotion of their competences. The education on quality and its promotion should, without any doubt, be observed in parallel. The implementation of the quality standard in a company does not enable the business performances improvement and does not bring significant effects, unless professional training and education, and rising of awareness on achieving quality are set as the common goal at the same time. Through knowledge creation and quality management, one realizes the complementary and independent impact on the organizational performances through the process of the organized learning (Choo, Linderman and Schroeder, 2007b). The basic goals of the management of knowledge and quality are the same - 
Cvjetković M.: Knowledge and quality as the factors of the business operations...

to create the organizational knowledge that can lead to the improvement that promotes competitiveness (Linderman et al, 2004; Loke et al, 2011; Ribière and Khorramshahgol, 2004).

\section{Literature review}

The key factors for achieving competitiveness are knowledge and quality. Knowledge management is a core competency for firms in the era of knowledge-based economies (Chon and, Chong. 2009; Grant and BadenFuller, 2004; Johannessen and Olsen, 2003). By improving its knowledge, a company creates a favorable environment for carrying out the quality system successful managing, which is certainly the precondition for competitiveness development in the global environment. In order to make knowledge the resource of competitive advantage, the companies have to coordinate the strategy of knowledge improvement with business strategy (Choo et al, 2007b). The economic growth in the developed countries, presented as scientific and technical knowledge, was used for raising labour productivity and other productive inputs. The systematic use of knowledge and science to produce goods and services increased very much the value of education and training of the employees (International Labour Organization, 2008). According to the research (Van Hemer and Nijkamp, 2011), the key factors in the developed countries are predominantly high technologies, innovations and development, high quality of human capital and knowledge advancing. According to other authors (Jha and Joshi, 2007), the business environment entered the knowledge era, where knowledge translates as power, while quick learning and competence become strong tendency for success. The aim of successful knowledge advancing is the business operations improvement (Jennex et al, 2009). Zack et al. (Zack, McKeen and Singh, 2009) established a positive direct relationship between knowledge management practices and organizational performance. Schein (2002) noted the difficulty in establishing a learning organization although knowledge is known to be a powerful source of firms' competitiveness.

Since knowledge management has its roots in numerous allied areas for the enhancement of business operations, this also applies for quality management, reengineering process, the information systems and human resources development. Many organizations found tensions between the applications oriented to knowledge and the execution of organizational changes (Moffett, McAdam and Parkinson, 2003). According to some authors (Akdere, 2009), the quality management applies knowledge management as one of its basic components. The knowledge management is the key element in the process of attaining business excellence. Without the knowledge change in the organization, the quality management can not achieve positive 
Cvjetković M.: Knowledge and quality as the factors of the business operations...

effects. Hung et al. (2010) showed that TQM is a mediator in the relationship between knowledge management and innovation. In contrast, Molina et al. (Molina, Llorens-Montes and Ruiz-Moreno, 2007) considered knowledge transfer as a mediator between TQM and performance. While some researchers considered knowledge management as a facilitator of TQM (Barber, Munive-Hernandez and Keane, 2006; Stewart and Waddell, 2008) other scholars regarded TQM as an antecedent of knowledge management (Colurcio, 2009; Jayawarna and Holt, 2009; Lin and Wu, 2005).

The quality management generates the organizational culture of confidence and division, which motivates the employees' commitment and the identification of the particular objectives, which spurs the quality promotion and knowledge creation to motivate innovations (Hung et al, 2011). Because of constant improvement, the quality praxis alleviates the other management praxis as the organizational learning (Ruiz-Moreno, Gracia-Morales and Lorens-Montes, 2005). This learning in the praxis of quality management is considered as the means that enables the companies to research new markets and contribute to their competitive advantage (Crossan, Lane and White, 1999). The quality management is connected with the theoretically founded organizational knowledge through its processes of continuing endeavor investment, cooperative knowledge creation, and adaption to the consumers' changes and needs (Chiles and Choi, 2000). The effective quality improvement depends on the influence of the organization on the cognitive processes of its members, and presents the problems as possibilities for learning (Choo et al, 2007b).

The implementation effects of the quality system on the business operations are confirmed in many researches. They show the strong impact on the improvement of the business performances, production quality and total competitiveness (Ruzevicius, Aomatiene and Sirvidaite, 2004), while other researchers (Saizarbitoria, Landín and $\mathrm{Fa}, 2006$ ) found higher participation of the employees and their motivation, as well greater clients' satisfaction. By improving business performances, the company becomes more competitive through the improvement of quality, delivery, flexibility and reducing expenses (Bruce and Chen, 2007).

The research results among large Slovenian companies show that the systematic use of quality approaches and tools as well as taking part in the award process including external assessment, has a positive effect on the development of TQM principles, organizational performance and financial results (Kern, Gomišček and Kljajić, 2014). According to the research conducted among Serbian companies (Spasojević Brkić et al, 2013), only quality tools for reviewing current condition (for decision making) have an important impact on financial performance measures. Some findings suggest that the cancelled ISO 9001 certificate could be understood as an early 
Cvjetković M.: Knowledge and quality as the factors of the business operations...

external signal indicating possible business problems in the organization (Alič, 2014).

\section{The research methodology}

The research was conducted in the Republic of Serbia from December $1^{\text {st }}$, 2013 to May $1^{\text {st }}, 2014$. The data were collected by electronic means with the help of an e-mail survey and by field surveys. A methodologically adapted questionnaire was created for the research. Besides general data, it contained the questions concerning the evaluation level of the company's business operations, the readiness of the company to invest into knowledge, the importance of training and employees' development and the rating of the considered quality aspects.

The size of the statistical sample presents main limitation of this research, while its originality lies in key results presenting the current state of Serbian economy at the time.

The targeted group in the research were the companies engaged in production, or services that conduct their business on the territory of the Republic of Serbia and the business operations based on the quality standard application (in the first place ISO 9001, and then also ISO 14001, OHSAS 18001, HACCP and others).

The research objective was to establish the relations between the quality aspects of the business operations level and competitiveness, and the readiness of the company to invest into knowledge, training and development of the employees in improving the quality aspects.

This research sets the following hypotheses:

- H1. By quality improvement, consciousness development and by including all the employees in quality achieving, a higher level of business operations and competitiveness of a company is being ensured.

- H2. Readiness of the company to invest into knowledge and to recognize the significance of professional training and development will enable the improvement of business operations quality.

\subsection{The research structure}

The size of the statistical sample is 140 companies, which includes $7.1 \%$ of micro, $31.4 \%$ of small, $32.1 \%$ of medium, and $29.3 \%$ of large companies. According to the data (The ISO Survey), the number of ISO 9001 certified 
Cvjetković M.: Knowledge and quality as the factors of the business operations...

companies in Serbia was 2366 in 2013, while the size of the statistical sample represented $6 \%$ of all certified companies.

Table 1. Descriptive statistics

\begin{tabular}{|c|c|c|c|c|c|c|}
\hline & Mark & $\mathrm{N}$ & Min & Max & Mean & $\begin{array}{c}\text { Std. } \\
\text { Deviation } \\
\end{array}$ \\
\hline Seat of the company & SC & 140 & 1 & 3 & 2,07 & ,675 \\
\hline Company proprietary structure & CS & 140 & 1 & 2 & 1,18 & ,384 \\
\hline Sex of the surveyed person & SSP & 140 & 1 & 2 & 1,46 &, 500 \\
\hline $\begin{array}{l}\text { Professional background of the } \\
\text { surveyed person }\end{array}$ & PBSP & 140 & 1 & 6 & 3,64 & $1,28 \mathrm{~S}$ \\
\hline Specialized training of the employees & STE & 140 & 1 & 2 & 1,44 & ,498 \\
\hline $\begin{array}{l}\text { Consciousness development on } \\
\text { quality achieving }\end{array}$ & DQA & 140 & 1 & 2 & 1,11 & ,310 \\
\hline $\begin{array}{l}\text { Execution of training program on } \\
\text { quality standards }\end{array}$ & TQS & 140 & 1 & 2 & 1,16 & ,365 \\
\hline Evaluation of technological level & ETL & 140 & 1 & 4 & 3,09 & ,758 \\
\hline $\begin{array}{l}\text { Evaluation of the investment level in } \\
\text { employees' training }\end{array}$ & EET & 140 & 1 & 4 & 2,77 & ,900 \\
\hline Evaluation of competitiveness level & $\mathrm{ECL}$ & 140 & 1 & 4 & 3,13 & ,838 \\
\hline $\begin{array}{l}\text { Significance of business operations } \\
\text { improvement }\end{array}$ & $\mathrm{SBI}$ & 140 & 1 & 4 & 2,89 & 1,091 \\
\hline $\begin{array}{l}\text { Significance of company } \\
\text { competitiveness improvement }\end{array}$ & $\mathrm{SCl}$ & 140 & 1 & 4 & 2,94 & 1,061 \\
\hline $\begin{array}{l}\text { Company readiness to invest in } \\
\text { knowledge }\end{array}$ & RIK & 140 & 1 & 4 & 2,57 & 1,040 \\
\hline $\begin{array}{l}\text { Significance of professional training } \\
\text { and development in the company }\end{array}$ & TDE & 140 & 1 & 4 & 2,31 & ,968 \\
\hline $\begin{array}{l}\text { Quality as personal responsibility of } \\
\text { every employee }\end{array}$ & Q1 & 140 & 1 & 5 & 3,56 & ,976 \\
\hline $\begin{array}{l}\text { The employees actively execute } \\
\text { constant improvements }\end{array}$ & Q2 & 140 & 1 & 5 & 3,37 & 1,055 \\
\hline $\begin{array}{l}\text { The employees are included in } \\
\text { defining the executive plans and } \\
\text { objectives }\end{array}$ & Q3 & 140 & 1 & 5 & 3,34 & 1,097 \\
\hline $\begin{array}{l}\text { The tasks of the employees are } \\
\text { adapted to the quality program }\end{array}$ & Q4 & 140 & 1 & 5 & 3,75 & ,866 \\
\hline $\begin{array}{l}\text { The employees are motivated to take } \\
\text { part in teamwork for quality } \\
\text { improvement }\end{array}$ & Q5 & 140 & 1 & 5 & 3,29 & 1,152 \\
\hline $\begin{array}{l}\text { The training system is adjusted to the } \\
\text { company development objectives }\end{array}$ & Q6 & 140 & 1 & 5 & 3,64 & 1,087 \\
\hline
\end{tabular}

Source: author calculation 
Cvjetković M.: Knowledge and quality as the factors of the business operations...

Table 1 provides the results of the descriptive statistics for the questions that show the achieved level of the company business operations and company competitiveness, the importance of company improvement of business operations, the significance of professional training and development, and recognition of quality aspects in the company. The table contains the variables abbreviations, which will be used further in the paper.

Table 2 presents the research data relating to the seat and the proprietary structure of the company.

Table 2. The research structure

\begin{tabular}{|l|l|c|c|}
\hline & & Frequency & Percent \\
\hline \multirow{3}{*}{ Company seat } & Vojvodina & 27 & $19,3 \%$ \\
\cline { 2 - 4 } & Belgrade & 76 & $54,3 \%$ \\
\cline { 2 - 4 } & Central Serbia & 37 & $26,4 \%$ \\
\hline \multirow{2}{*}{$\begin{array}{l}\text { Company proprietary } \\
\text { structure }\end{array}$} & Private & 115 & $82,1 \%$ \\
\cline { 2 - 4 } & State & 25 & $17,9 \%$ \\
\hline \multirow{2}{*}{$\begin{array}{l}\text { Sex of the surveyed } \\
\text { person }\end{array}$} & Males & 76 & $54,3 \%$ \\
\cline { 2 - 4 } & Females & 64 & $45,7 \%$ \\
\hline \multirow{2}{*}{$\begin{array}{l}\text { Professional back } \\
\text { ground of the }\end{array}$} & $\mathrm{IV}$ & 19 & $13,6 \%$ \\
\cline { 2 - 4 } & $\mathrm{V}$ & 3 & $2,1 \%$ \\
\cline { 2 - 4 } & $\mathrm{VI}$ & 21 & $15 \%$ \\
\cline { 2 - 4 } & $\mathrm{VII} / 1$ & 70 & $50 \%$ \\
\cline { 2 - 4 } & $\mathrm{VIII} / 2$ & 21 & $15 \%$ \\
\cline { 2 - 4 } & $\mathrm{VIII}$ & 6 & $4,3 \%$ \\
\hline
\end{tabular}

Source: author calculation

Table 3 presents questions that show the company's relation to the employees from the training aspect, specialized training and raising awareness on achieving quality.

Table 3. The relation of the company to the employees from the aspects of training, specialized training and consciousness development on quality achieving

\begin{tabular}{|l|c|c|c|}
\hline & & Frequency & Percent \\
\hline \multirow{2}{*}{$\begin{array}{l}\text { Did any employee attend } \\
\text { specialized training }\end{array}$} & Yes & 79 & $56,4 \%$ \\
\cline { 2 - 4 } $\begin{array}{l}\text { Is awareness on quality } \\
\text { achievement raised }\end{array}$ & No & 61 & $43,6 \%$ \\
\cline { 2 - 4 } $\begin{array}{l}\text { Is the training program on } \\
\text { quality standards executed }\end{array}$ & No & 125 & $89,3 \%$ \\
\cline { 2 - 4 } & Yes & 15 & $10,7 \%$ \\
\hline
\end{tabular}

Source: author calculation 
Cvjetković M.: Knowledge and quality as the factors of the business operations...

\subsection{Correlation and regressive analysis}

On the basis of the correlation among the evaluation of level of business operations, knowledge improvement and quality aspects in Serbian companies, we shall prove the assigned hypotheses.

\begin{tabular}{|c|c|c|c|c|c|c|c|c|c|c|c|c|c|}
\hline$z$ & $\underset{ }{\stackrel{P}{\prime}}$ & $\underset{\sim}{\stackrel{P}{-}}$ & 억 & $\underset{\sim}{\stackrel{ }{4}}$ & $\underset{ }{\stackrel{P}{-}}$ & $\underset{ }{\stackrel{P}{7}}$ & $\underset{ }{\stackrel{P}{r}}$ & 守 & $\underset{ }{\stackrel{P}{7}}$ & $\underset{ }{\stackrel{P}{\prime}}$ & $\underset{\sim}{\stackrel{P}{r}}$ & $\underset{\sim}{\stackrel{ }{r}}$ & $\underset{ }{\stackrel{P}{+}}$ \\
\hline$\vec{w}$ & $r$ & $\stackrel{*}{\stackrel{*}{6}}$ & $\begin{array}{l}{ }^{*} \mathbb{0} \\
\stackrel{0}{0} \\
0\end{array}$ & 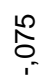 & o̊. & 華 & $\begin{array}{l}{ }^{*} \infty \\
\stackrel{0}{\longrightarrow} \\
\neg\end{array}$ & ": & 荬 & 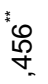 & 范 & 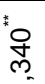 & $\stackrel{\text { * }}{\text { Pु }}$ \\
\hline 点 & 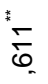 & - & م. & o & $\stackrel{\infty}{\underset{\sim}{\sim}}$ & $\stackrel{*}{\stackrel{*}{*}}$ & î & 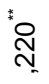 & 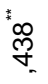 & $\stackrel{*}{\stackrel{*}{*}}$ & 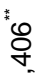 & $\stackrel{*}{\underset{*}{\sim}}$ & 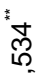 \\
\hline 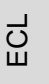 & $\begin{array}{l}{ }^{*} \times \\
0 \\
0 \\
0\end{array}$ & مִ & $\neg$ & 点 & 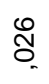 & 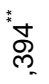 & $\underset{\sim}{\stackrel{\text { I }}{-1}}$ & 苂 & 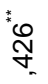 & ". & $\begin{array}{l}\text { *0 } \\
\text { 림 }\end{array}$ & $\begin{array}{l}* \\
\text { : } \\
\stackrel{2}{0}\end{array}$ & *용 \\
\hline$\overline{\mathrm{m}}$ & $\begin{array}{l}\stackrel{0}{\circ} \\
0^{-}\end{array}$ & Oo & ${ }^{-1}$ & $\neg$ & $\begin{array}{l}* 0 \\
0 \\
0\end{array}$ & $\stackrel{\infty}{\text { O }}$ & $\begin{array}{l}\hat{N} \\
\text { O } \\
1^{-}\end{array}$ & 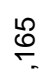 & oิ & 긍 & : & 용 & 옹 \\
\hline $\bar{\omega}$ & oे & $\stackrel{\infty}{\sim}$ & 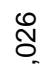 & $\begin{array}{l}* 0 \\
01 \\
0\end{array}$ & $r$ & مొ & $\Xi_{0}$ & $\mathscr{\varnothing}$ & $\underset{\neg}{\stackrel{\leftarrow}{\sim}}$ & $\stackrel{\stackrel{L}{O}}{\stackrel{0}{O}}$ & స్ర & 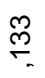 & $\underset{\sim}{\stackrel{\sim}{\sim}}$ \\
\hline$\frac{\underline{\underline{\underline{\alpha}}}}{}$ & 苋 & $\stackrel{*}{\stackrel{*}{\sim}}$ & 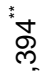 & $\stackrel{\infty}{0}$ & 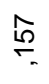 & $r$ & $\stackrel{\stackrel{\leftrightarrow}{\oplus}}{\rightarrow}$ & 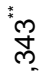 & 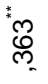 & ભ & 类 & 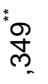 & 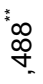 \\
\hline$\stackrel{\text { 岁 }}{\mapsto}$ & $\begin{array}{l}\text { *0 } \\
\infty \\
\rightarrow \\
\rightarrow\end{array}$ & $\stackrel{*}{*} \stackrel{\sim}{\sim}$ & $\underset{ }{\stackrel{ }{-1}}$ & 令 & $\mathbb{O}_{i}^{+}$ & 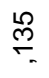 & $r$ & g & $\stackrel{*}{\stackrel{*}{\sim}}$ & $\begin{array}{l}\text { *- } \\
\text { ने } \\
\text { - }\end{array}$ & $\stackrel{\text { In }}{\stackrel{N}{N}}$ & 華 & $\stackrel{*}{\stackrel{*}{N}}$ \\
\hline$\tilde{\sigma}$ & 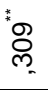 & * & 草 & 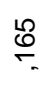 & $\dddot{\mathscr{\ell}}$ & "ָ & g̊ & $\neg$ & 葛 & $\begin{array}{l}\text { * } \\
\text { N̦ } \\
\text { గn }\end{array}$ & 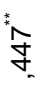 & $\begin{array}{l}{ }^{*} \infty \\
\stackrel{\infty}{\sim}\end{array}$ & $\begin{array}{l}\stackrel{*}{\sim} \\
\stackrel{v}{+}\end{array}$ \\
\hline$\widetilde{\sigma}$ & to & 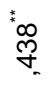 & 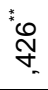 & 용 & $\underset{\sim}{\stackrel{\sim}{\sim}}$ & 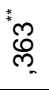 & $\stackrel{\text { * }}{\underset{\sim}{J}}$ & 类 & -1 & $\begin{array}{l}\text { * } \\
\stackrel{*}{-} \\
\end{array}$ & مِ & م & مِ مِ \\
\hline$\stackrel{m}{O}$ & $\begin{array}{l}\text { *o } \\
\text { 吊 }\end{array}$ & $\stackrel{*}{\stackrel{*}{+}}$ & 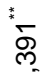 & స్ & 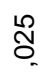 & $\stackrel{\text { * }}{\text { ָे }}$ & & $\begin{array}{l}* \\
\text { กิ } \\
\text { గి }\end{array}$ & $\begin{array}{l}{ }^{*} \\
\\
\end{array}$ & $r$ & ". & 華 & ${ }^{*} \infty$ \\
\hline O & 苂 & "o & $\begin{array}{l}* 0 \\
\text { 음 } \\
\text { 음 }\end{array}$ & స్రి & 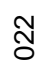 & 䒜 & $\stackrel{\text { In }}{\stackrel{N}{N}}$ & $\stackrel{*}{\stackrel{*}{f}}$ & 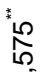 & 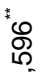 & -1 & 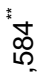 & $\stackrel{*}{\stackrel{*}{ }}$ \\
\hline$\stackrel{L}{O}$ & ". & $\stackrel{*}{\underset{\sim}{*}}$ & 苂 & 용 & $\stackrel{\underset{\sim}{\longrightarrow}}{\longrightarrow}$ & 苂 & "ָ̊ & $\stackrel{*}{\infty} \stackrel{\infty}{\stackrel{f}{\forall}}$ & 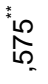 & $\stackrel{*}{7}$ & 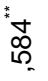 & -1 & $\begin{array}{l}* 0 \\
\stackrel{0}{0} \\
0 \\
0\end{array}$ \\
\hline $\mathscr{O}$ & 莓 & مొ & 웅 & Õ & $\stackrel{\overbrace{}}{\sim}$ & 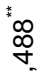 & 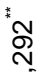 & $\begin{array}{l}* \\
\stackrel{*}{\mathbb{N}} \\
\underset{V}{*}\end{array}$ & : & $\begin{array}{l}{ }^{*} \infty \\
0 \\
0 \\
0\end{array}$ & . & $\begin{array}{l}{ }^{*} 0 \\
0 \\
0 \\
0\end{array}$ & $r$ \\
\hline & $\vec{w}$ & 岀 & $\vec{U}$ & $\overline{\bar{n}}$ & $\bar{c}$ & $\frac{\underline{Y}}{\underline{\underline{x}}}$ & 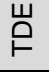 & ö & $\widetilde{\sigma}$ & $\ddot{O}$ & 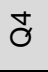 & $\stackrel{\sim}{O}$ & $\mathscr{8}$ \\
\hline
\end{tabular}


Cvjetković M.: Knowledge and quality as the factors of the business operations...

On the basis of the presented correlation results, we can confirm $\mathrm{H} 1$ on the basis of the next correlations:

ETL and Q1, Q2, Q3, Q4, Q5, Q6

EET and Q1, Q2, Q3, Q4, Q5, Q6

ECL and Q1, Q2, Q3, Q4, Q5, Q6

We confirm $\mathrm{H} 2$ on the basis of the next correlations:

RIK and Q1, Q2, Q3, Q4, Q5, Q6

TDE and Q2, Q3, Q4, Q5, Q6

In the companies, which have high technological level of business operations and which improve their technical - technological base of the business operations, there is obviously significant correlation between the considered quality aspects. The companies, which focus on improvement of business operations based on new equipment and modern technologies, have to be ready to adequately guide their employees, regarding the quality enhancement. The employees are being motivated to participate in teamwork, to actively execute constant improvements, and that their tasks are coordinated with the quality program. The companies that recognize the significance of the human resources and permanent professional training and improvement, raise the awareness of their employees on achieving the quality as personal responsibility of every individual, on active execution of constant enhancements, as well on the emphasis of teamwork among the employees. In such companies, the training system is coordinated with the quality programs, and the employees are included in defining of the executive plans and objectives. The positive and significant correlation exists between the considered quality aspects and the achieved competitiveness level. The companies, which are ready to improve the system of quality management, on the basis of the standardized quality of business operations and the adequate training and improvement of the employees on the standard execution, impact the increase of competitive capabilities of the company on the market. The mentioned relations confirm the hypothesis 1 , i.e. quality improvement, raising awareness and including all employees in quality achievement process, enable higher level of business operations and company competitiveness.

The companies that demonstrated their capability to invest in knowledge recognized quality as the factor of business operations improvement. It is confirmed by the correlation between these companies and the training significance, and professional development and the considered quality aspects. The correlation may be considered as significant one, but not for all aspects. Namely, the variable that relates to the quality as the personal responsibility of all the employees is omitted, while the impact on the other quality aspects is evident. These relations confirm the hypothesis 2 , i.e. the 
Cvjetković M.: Knowledge and quality as the factors of the business operations...

company's readiness to invest in knowledge, professional training and development will enable the improvement of business operations quality.

The cited hypotheses will be confirmed once more through the relation among the level of business operations, knowledge improvement and quality aspects considered in the companies where the awareness of quality achieving is developed and in those where it isn't. Table 5 presents the descriptive statistics of the relations of the considered variables with the companies which claimed that they developed the awareness of achieving quality with the employees, and with the companies which answered negatively.

Table 5. Descriptive statistics

\begin{tabular}{|c|c|c|c|c|r|}
\hline $\begin{array}{c}\text { Is employees' awareness } \\
\text { on achieving quality is } \\
\text { raised }\end{array}$ & N & Min & Max & Mean & $\begin{array}{c}\text { Std. } \\
\text { Deviation }\end{array}$ \\
\hline Yes & 125 & 1 & 4 & 3,18 &, 708 \\
\hline EET & 125 & 1 & 4 & 2,87 &, 852 \\
\hline ECL & 125 & 1 & 4 & 3,21 &, 765 \\
\hline SBI & 125 & 1 & 4 & 2,86 & 1,102 \\
\hline SCl & 125 & 1 & 4 & 2,96 & 1,035 \\
\hline RIK & 125 & 1 & 4 & 2,67 & 1,006 \\
\hline TDE & 125 & 1 & 4 & 2,34 &, 934 \\
\hline Q1 & 125 & 1 & 5 & 3,70 &, 880 \\
\hline Q2 & 125 & 1 & 5 & 3,56 &, 919 \\
\hline Q3 & 125 & 1 & 5 & 3,43 & 1,065 \\
\hline Q4 & 125 & 1 & 5 & 3,86 &, 820 \\
\hline Q5 & 125 & 1 & 5 & 3,44 & 1,066 \\
\hline Q6 & 125 & 1 & 5 & 3,79 &, 961 \\
\hline ETL & 15 & 1 & 4 & 2,40 &, 828 \\
\hline EET & 15 & 1 & 4 & 1,93 &, 884 \\
\hline ECL & 15 & 1 & 4 & 2,47 & 1,125 \\
\hline SBI & 15 & 1 & 4 & 3,13 &, 990 \\
\hline SCl & 15 & 1 & 4 & 2,73 & 1,280 \\
\hline RIK & 15 & 1 & 4 & 1,73 &, 961 \\
\hline TDE & 15 & 1 & 4 & 2,07 & 1,223 \\
\hline Q1 & 15 & 1 & 4 & 2,33 &, 900 \\
\hline Q2 & 15 & 1 & 3 & 1,80 &, 775 \\
\hline Q3 & 15 & 1 & 4 & 2,53 & 1,060 \\
\hline Q4 & 15 & 1 & 4 & 2,87 &, 743 \\
\hline Q5 & 15 & 1 & 4 & 2,00 & 1,069 \\
\hline Q6 & 15 & 1 & 5 & 2,40 & 1,298 \\
\hline No & & & & & \\
\hline
\end{tabular}

Source: author calculation

Table 6 and 7 present the correlation among the level of business operations, knowledge improvement and quality aspects and the relation between the 
Cvjetković M.: Knowledge and quality as the factors of the business operations...

company and its employees regarding awareness raising on quality achievement.

\begin{tabular}{|c|c|c|c|c|c|c|c|c|c|c|c|c|c|}
\hline$z$ & $\stackrel{\stackrel{\sim}{7}}{\underset{\sim}{\mid c}}$ & $\stackrel{\stackrel{N}{\sim}}{\exists}$ & $\stackrel{\stackrel{\sim}{\sim}}{\neg}$ & $\stackrel{\stackrel{\sim}{\sim}}{\sim}$ & $\stackrel{\stackrel{\sim}{\sim}}{\neg}$ & $\stackrel{\stackrel{\sim}{\sim}}{\neg}$ & $\stackrel{\stackrel{n}{\sim}}{\sim}$ & $\stackrel{\stackrel{N}{\sim}}{\Im}$ & $\stackrel{\stackrel{n}{\sim}}{\sim}$ & $\stackrel{\stackrel{\sim}{\sim}}{\rightarrow}$ & $\stackrel{\stackrel{\sim}{\sim}}{\sim}$ & $\stackrel{\llcorner}{\stackrel{\sim}{\sim}}$ & $\stackrel{\stackrel{\sim}{\sim}}{\sim}$ \\
\hline$\vec{E}$ & -1 & 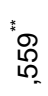 & 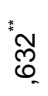 & $\begin{array}{l}0 \\
\text { Oे } \\
\text { i- }\end{array}$ & o̊ & 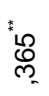 & กี & $\stackrel{*}{\stackrel{*}{N}}$ & 萬 & 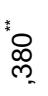 & 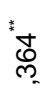 & $\stackrel{\text { * }}{\stackrel{\text { I }}{\mathrm{N}}}$ & ". \\
\hline 岀 & 萬 & - & م. & $\begin{array}{l}0 \\
\stackrel{-1}{0}\end{array}$ & $\underset{\sim}{\stackrel{N}{\sim}}$ & 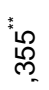 & $\stackrel{n}{\sim}$ & $\underset{\sim}{\stackrel{m}{+}}$ & $\begin{array}{l}\text { ? } \\
\text { ? } \\
\text { m }\end{array}$ & 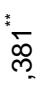 & 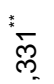 & 莡 & * \\
\hline$\vec{U}$ & ్ָల్ల్ & 范 & $\dashv$ & 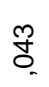 & 농 & 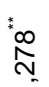 & 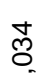 & $\begin{array}{l}* \\
\end{array}$ & مِ & 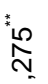 & $\underset{\sim}{*}$ & & $\begin{array}{l}* \\
\stackrel{*}{*}\end{array}$ \\
\hline$\overline{\tilde{\omega}}$ & 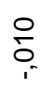 & $\begin{array}{l}0 \\
0 \\
0\end{array}$ & ঙ্ণ & $\rightarrow$ & 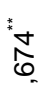 & $\stackrel{\infty}{\underset{\sim}{+}}$ & $\mathscr{ஜ}_{i}$ & $\underset{*}{\stackrel{N}{N}}$ & $\stackrel{*}{\stackrel{*}{N}}$ & : & $\stackrel{\mathbb{N}}{0}$ & 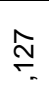 & o̊ \\
\hline $\begin{array}{l}\bar{U} \\
\text { Un }\end{array}$ & o̊ & $\underset{\sim}{\stackrel{N}{\sim}}$ & 롱 & $\frac{\text { * }}{\stackrel{*}{0}}$ & $\dashv$ & $\stackrel{*}{*} \underset{\sim}{\stackrel{N}{*}}$ & ষ্ & $\begin{array}{l}\infty \\
\stackrel{\circ}{O}\end{array}$ & $\underset{\sim}{\stackrel{\sim}{\sim}}$ & 형 & $\underset{O}{\stackrel{Y}{0}}$ & ్ָ & \& \\
\hline$\frac{\underline{\underline{x}}}{\underline{\underline{x}}}$ & 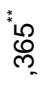 & مِ & $\stackrel{*}{\stackrel{*}{\stackrel{\infty}{N}}}$ & $\stackrel{\infty}{\underset{\sim}{+}}$ & $\underset{\sim}{\stackrel{N}{ }}$ & -1 & $\begin{array}{l}\text { o } \\
0\end{array}$ & $\stackrel{*}{\stackrel{*}{N}}$ & $\stackrel{\text { N }}{\stackrel{*}{N}}$ & $\stackrel{*}{\stackrel{*}{*}}$ & $\stackrel{*}{\stackrel{m}{m}}$ & 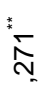 & $\stackrel{*}{\stackrel{*}{F}} \underset{\sim}{\sigma}$ \\
\hline$\stackrel{\text { 岁 }}{口}$ & ָָ & $\stackrel{\overbrace{}}{\stackrel{2}{\sim}}$ & స్ల్ & $\mathscr{ஜ}_{0}$ & O্ & 各 & -1 & $\hat{\tilde{g}}$ & $\stackrel{\text { N }}{\stackrel{N}{N}}$ & $\underset{\bullet}{\stackrel{\bullet}{\hookrightarrow}}$ & ั & "ºn & $\stackrel{*}{\mathbb{N}}$ \\
\hline$\stackrel{-1}{0}$ & $\stackrel{*}{\stackrel{*}{N}}$ & $\stackrel{m}{\underset{\sim}{-}}$ & 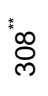 & $\underset{N}{\stackrel{*}{N}}$ & $\begin{array}{l}\infty \\
\stackrel{్}{O}\end{array}$ & $\stackrel{*}{\stackrel{*}{N}}$ & $\hat{\tilde{O}}$ & - & مِ & $\stackrel{*}{*}$ & 芦 & 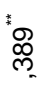 & 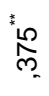 \\
\hline 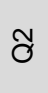 & . & $\begin{array}{l}\text { *0 } \\
\text { ? } \\
\text { m }\end{array}$ & مِ & $\stackrel{*}{*}$ & $\stackrel{\sim}{\underset{\sim}{f}}$ & 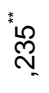 & 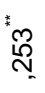 & مِ & -1 & $\frac{\text { * }}{\stackrel{*}{L}}$ & 范 & 草 & $\begin{array}{l}{ }^{*} \\
{ }^{*}\end{array}$ \\
\hline$\tilde{O}$ & $\begin{array}{l}\text { *0. } \\
\text { \& } \\
\text { r. }\end{array}$ & 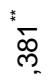 & مِ & 용 & $\overrightarrow{8}$ & $\stackrel{*}{\stackrel{0}{\sim}}$ & $\underset{\nearrow}{\mathscr{C}}$ & 草 & 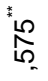 & -1 & 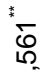 & ") & 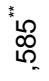 \\
\hline$\stackrel{\Delta}{O}$ & 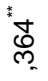 & $\stackrel{*}{\text { m}}$ & $\underset{+}{\stackrel{*}{\mathbb{N}}}$ & $\stackrel{\mathscr{O}}{\mathrm{O}}$ & $\stackrel{\sim}{-1}$ & $\stackrel{\text { *n }}{\stackrel{\text { N }}{m}}$ & ָ & 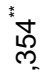 & 范 & 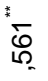 & $-r$ & 莣 & $\begin{array}{l}{ }^{*} \infty \\
0 \\
0 \\
0\end{array}$ \\
\hline$\stackrel{\llcorner}{\circ}$ & $\stackrel{\text { * }}{\stackrel{\text { S }}{+}}$ & $\underset{m}{\stackrel{*}{*}}$ & 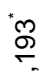 & $\underset{\sim}{\stackrel{\sim}{\sim}}$ & 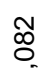 & 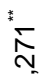 & 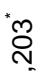 & $\begin{array}{l}\text { * } \\
\text { \% } \\
\text { ల్ }\end{array}$ & 俈 & : & 莳 & 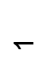 & $\begin{array}{l}{ }^{*} \\
\stackrel{0}{0}\end{array}$ \\
\hline 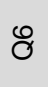 & "\% & 莡 & $\frac{{ }^{*}}{\stackrel{0}{\sim}}$ & o̊ & : & $\stackrel{*}{\underset{7}{*}}$ & $\stackrel{*}{\underset{N}{N}}$ & 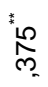 & م & 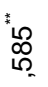 & $\begin{array}{l}{ }^{*} \infty \\
0 \\
0 \\
0\end{array}$ & $\begin{array}{l}{ }^{*} m \\
\stackrel{n}{0}\end{array}$ & $\dashv$ \\
\hline & $\vec{E}$ & 岀 & $\overrightarrow{\mathrm{U}}$ & $\overline{\mathbf{m}}$ & $\bar{U}$ & $\frac{\underline{Y}}{\underline{\underline{Y}}}$ & 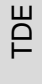 & 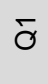 & $\widetilde{\sigma}$ & $\stackrel{\mathscr{O}}{O}$ & $\ddot{O}$ & $\stackrel{\sim}{0}$ & $\stackrel{\circ}{\circ}$ \\
\hline
\end{tabular}


Cvjetković M.: Knowledge and quality as the factors of the business operations...

\begin{tabular}{|c|c|c|c|c|c|c|c|c|c|c|c|c|c|}
\hline$z$ & $\stackrel{\sim}{\sim}$ & $\stackrel{\sim}{\sim}$ & $\stackrel{\llcorner}{\sim}$ & $\stackrel{\leftrightarrow}{\sim}$ & $\stackrel{\sim}{\sim}$ & $\stackrel{\sim}{\sim}$ & 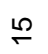 & $\stackrel{\sim}{\circ}$ & $\stackrel{\sim}{\circ}$ & 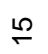 & $\stackrel{\sim}{\sim}$ & $\stackrel{\sim}{\sim}$ & $\stackrel{\sim}{\circ}$ \\
\hline$\vec{b}$ & $\dashv$ & & 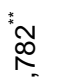 & $\stackrel{\infty}{\underset{7}{+}}$ & 옹 & 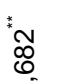 & $\stackrel{\stackrel{*}{N}}{N}$ & ஜ. & $\stackrel{\text { I }}{\underset{N}{N}}$ & "*n్లై & $\stackrel{\stackrel{N}{N}}{\stackrel{m}{n}}$ & $\stackrel{\sim}{\sim}$ & 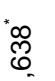 \\
\hline 苫 & $\stackrel{*}{\stackrel{*}{*}}$ & $\dashv$ & $\underset{+}{+}$ & $\begin{array}{l}0 \\
m \\
m \\
i\end{array}$ & o & $\stackrel{\sim}{\infty} \underset{+}{+}$ & ờ & 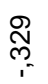 & ה్ & 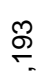 & సี & \begin{tabular}{l}
0 \\
\multirow{0}{0}{} \\
0
\end{tabular} & *0. \\
\hline 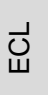 & 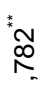 & ষ্ণ & $\dashv$ & . & 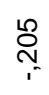 & 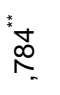 & ఖ్ల్ & 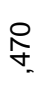 & " & $\stackrel{*}{\text { 范 }}$ & $\stackrel{\vec{N}}{\underset{\sim}{*}}$ & 용 & 莓 \\
\hline $\begin{array}{l}\bar{m} \\
\dot{\omega}\end{array}$ & $\underset{+}{\stackrel{\infty}{+}}$ & $\begin{array}{l}0 \\
m \\
m\end{array}$ & , & -1 & $\stackrel{\stackrel{n}{N}}{N}$ & , & ণ్ & 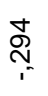 & $\stackrel{\infty}{\underset{\sim}{\sim}}$ & $\hat{G}$ & 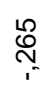 & 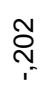 & , \\
\hline $\bar{U}$ & 옹 & O্ & $\underset{\sim}{\stackrel{N}{N}}$ & $\stackrel{\stackrel{\sim}{N}}{N}$ & $-r$ & 孞 & 足 & 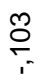 & ণิ & 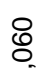 & 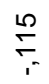 & $\begin{array}{l}\text { L } \\
\text { ల్ }\end{array}$ & $\stackrel{\infty}{\stackrel{\infty}{\neg}}$ \\
\hline$\frac{\underline{Y}}{\overline{\underline{\Sigma}}}$ & $\begin{array}{l}\text { * } \\
0 \\
0 \\
0\end{array}$ & $\stackrel{\sim}{\stackrel{\infty}{+}}$ & 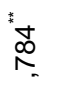 & , & ஸ్ & -1 & ণ্లె & 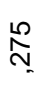 & "* & * 옹 & 每 & $\underset{\sim}{\stackrel{\infty}{N}}$ & *9 \\
\hline$\stackrel{w}{\stackrel{\leftrightarrow}{\bullet}}$ & *ด & 무 & ఖ్లి & ల్ & $\begin{array}{l}\infty \\
\stackrel{\nu}{0}\end{array}$ & ঙ্ল & $-r$ & 롬 & 용 & $\stackrel{O}{\stackrel{N}{*}}$ & $\begin{array}{l}\infty \\
\stackrel{0}{0}\end{array}$ & 占 & 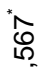 \\
\hline 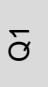 & ஜㅁ & 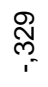 & $\stackrel{?}{\stackrel{f}{f}}$ & $\underset{\sim}{\stackrel{D}{S}}$ & 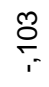 & 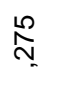 & 点 & -1 & . & 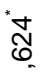 & $\stackrel{\stackrel{\infty}{\infty}}{\stackrel{\infty}{N}}$ & $\stackrel{\sim}{N}$ & $\underset{\sim}{\stackrel{N}{*}}$ \\
\hline$\approx$ & $\stackrel{\text { I }}{N}$ & त્ন & " & 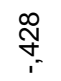 & 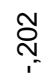 & " & ㅇ. & 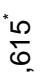 & -1 & $\stackrel{*}{\stackrel{*}{N}}$ & f & 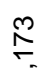 & 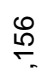 \\
\hline$\stackrel{m}{O}$ & " & $\underset{\sim}{\stackrel{\leftrightarrow}{\sim}}$ & * & $\stackrel{\hat{G}}{\hat{6}}$ & 8 & *0 & $\stackrel{\mathscr{V}}{\sim}$ & * & $\stackrel{*}{\text { * }}$ & -1 & 每员 & $\stackrel{\sim}{\stackrel{n}{m}}$ & ஜे \\
\hline ठ & $\stackrel{\stackrel{n}{N}}{\underset{n}{n}}$ & $\stackrel{\sim}{\text { ஸे }}$ & $\stackrel{\check{\Im}}{\underset{\sim}{*}}$ & 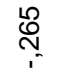 & $\stackrel{\stackrel{\rho}{\rightarrow}}{\underset{\sim}{\sim}}$ & 莳 & $\begin{array}{l}\infty \\
\stackrel{\leftrightarrow}{\sim}\end{array}$ & $\stackrel{\stackrel{L}{\infty}}{\stackrel{\sim}{N}}$ & f & 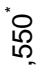 & $\dashv$ & 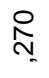 & חల్ \\
\hline$\stackrel{\text { O̊ }}{\circ}$ & $\stackrel{\sim}{\stackrel{\sim}{\sim}}$ & 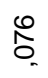 & 용 & 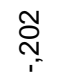 & 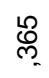 & $\stackrel{\infty}{\stackrel{\infty}{N}}$ & 虽 & $\stackrel{\cong}{N}$ & 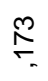 & $\stackrel{\text { Dी }}{\stackrel{n}{n}}$ & $\stackrel{?}{\stackrel{P}{N}}$ & -1 & ஓे \\
\hline $\mathscr{O}$ & $\begin{array}{l}{ }^{*} \infty \\
\overparen{్} \\
6\end{array}$ & 옹. & * & 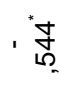 & $\stackrel{\infty}{\stackrel{\overbrace{}}{ }}$ & *요 & 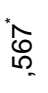 & $\underset{\sim}{\stackrel{\overbrace{}}{*}}$ & 足 & 总 & ஜొ & : & $r$ \\
\hline & $\vec{E}$ & 岀 & $\vec{U}$ & $\overline{\text { 心 }}$ & $\bar{U}$ & $\frac{\underline{\underline{x}}}{\underline{\underline{\alpha}}}$ & $\stackrel{\text { 㟔 }}{口}$ & $\widetilde{O}$ & $\widetilde{\sigma}$ & O̊ & む & $\stackrel{\llcorner}{O}$ & $\mathscr{8}$ \\
\hline
\end{tabular}


Cvjetković M.: Knowledge and quality as the factors of the business operations...

Given the presented results of correlation, $\mathrm{H} 1$ can be confirmed on the basis of the next correlation between the companies that raise employees' awareness on quality achievement:

ETL and Q1, Q2, Q3, Q4, Q5, Q6

EET and Q2, Q3, Q4, Q5, Q6

ECL and Q1, Q2, Q3, Q4, Q5, Q6

SBI and Q1, Q2

We confirm $\mathrm{H} 2$ on the basis of the next correlation:

RIK and Q1, Q2, Q3, Q4, Q5, Q6

TDE and Q2, Q4, Q5 Q6

For companies that did not raise employees' awareness on quality achievement, we confirm $\mathrm{H} 1$ on the basis of the negative correlation:

SBI and Q3, Q6

The observed relations between the achieved level of business operations and quality aspects, as well the company's readiness to invest in knowledge and quality aspects, show a positive and significant correlation among the considered variables. Given the relation between the training significance and professional development and quality aspects, there is no significant correlation between all observed quality variables. This confirms once more the fact that Serbian companies did not conduct the adequate training or professional development. In companies that raised awareness on quality achievement, there is an important relation between the significance of business operations enhancement and the observed aspects of quality: quality as personal responsibility of all the employees and they actively execute constant improvements. This confirms the fact that the companies, which are ready to perform professional improvement and raise awareness on quality achievement, recognize the importance of quality as the factor for business operations enhancement. In such companies, the employed are actively included in the process of quality creation and continuing execution of constant improvements. Only with such philosophy on business operations and awareness of all employees, a company can adapt to the challenges of the changeable market and improve its competitive position.

When the relations of the observed variables are analyzed in the companies where awareness of quality performance is not being developed, the adverse correlations can be noticed. In these companies, the relations among the attained level of business relations, the quality aspects, and the competitiveness of the company to invest in knowledge and quality aspects, indicate the significant correlation only for the next observed quality variables: the employees are included in defining the executive plans and objectives and the training system is coordinated with the developing objectives of the 
Cvjetković M.: Knowledge and quality as the factors of the business operations...

company. The relation between the training importance, the development of employees and the quality aspects represents a significant correlation only for the observed variable that the training system is coordinated with the developing objectives of the company. In the companies that do not develop the awareness of quality achieving, the training and development of the employees regarding the improvement of the observed quality aspects obviously don't exist. In such companies, the employees are forced to specialize and learn on their own in order to follow the changes that happen in business operations. In such a business environment, the employees are not motivated to execute constant improvements actively and to take part in quality attaining. Considering this, the companies are not able to reach a high level of business operations and competitiveness. In such companies, the dissatisfaction among the employees appears. The negative correlation between the significance of the improvement of business operations and the observed quality variables also confirms that the employees are included in defining the executive plans and objectives and that the training system is in accordance with the company's developing objectives.

The regressive method examined the contribution of the independent variables Q1, Q2, Q3, Q4, Q5, Q6 for total R regression square with the independent variables ETL, EET, ECL, RIK TDE. On the basis of the regression model, as it is represented in the figure 1 , one can see that the quality aspects are the best predictors of the level of business operations competitiveness $\left(R^{2}=0,403\right)$ of Serbian companies. Therefore, the highest impact on the improvement of competitiveness capability is exercised by the enhancement of quality aspects, i.e., the quality explains $40.3 \%$ variations of the level of companies' competitiveness.

The greatest impact on the competitive level is showed by the next variables: Q1 (quality as personal responsibility of all employees), Q4 (the tasks of the employees are adapted to the quality program), Q5 (the employees are motivated for teamwork for quality improvement), Q6 (the training system is coordinated with company's development objectives). Variable Q6 has the greatest impact on the next variables EET (level of investment in training), RIK (company's readiness to invest in knowledge), variable Q2 (the employees actively execute constant improvements) has the greatest impact on the variable EET (level of investment in training), while the variable Q3 (the employees are included in defining the executive plans and objectives) has the greatest impact on the variable ETL (technological level of business operations). None of the observed variables Q1, Q2, Q3, Q4, Q5, Q6 exhibited an impact on the companies which did not recognize the significance of training and of the employees development. 
Cvjetković M.: Knowledge and quality as the factors of the business operations...

Figure 1. The regression model of the influence of quality aspects on the level of business operations and enhancement of knowledge in the companies in Serbia

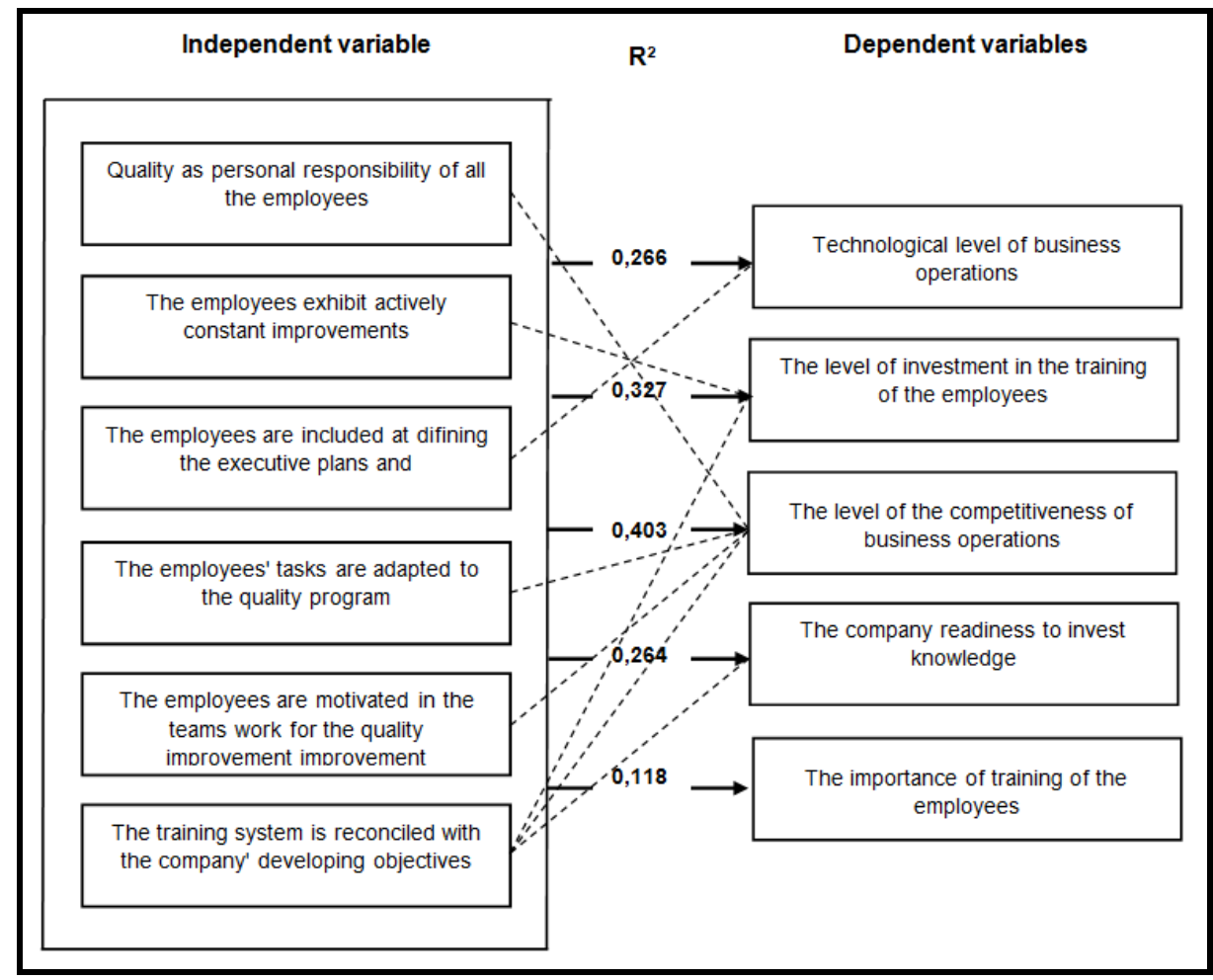

Source: author calculation

All $R^{2}$ values are statistically important. The observed quality aspects show the greatest importance in promoting competitiveness, while they show the least significant effect on professional training and development. This emphasizes the fact that quality contributes to competitiveness promotion. However, without adequate education and rasing awareness on quality achievement, it will be hard to reach a higher level of business operation. If a company wants to improve its competitiveness and its business operations, the employees have to be trained in accordance with the quality program and focused on teamwork and quality achievement as a common goal. 
Cvjetković M.: Knowledge and quality as the factors of the business operations...

\section{Conclusion}

The scientific contribution of the presented research is being reflected in establishing the significance of knowledge and quality in the improvement of business operations and competitiveness of the companies in Serbia. The above mentioned is necessary, so that they could realize better market position in the international frames of business operations. Moreover, the mentioned researches show that it is necessary to raise employees' awareness on quality achievement as the factor of business operations improvement. It is of exceptional importance for Serbian companies to realize that it is necessary to change the way and the philosophy of business operations in the future.

The research results can be useful to Serbian managers, but also to other small economies and developing countries which face the same problems in business operations of their companies. This research can help managers and researchers be better informed on the role and significance of the improvement of knowledge and qualities for the achieved level of business operations and competitiveness. Managers can use the results of this research to provide the employees with adequate aspects of training and development in order to improve the analyzed quality aspects. It would cause higher level of competitiveness of business operations. Besides that, managers can, on the basis of the results, realize the significance in companies that raised employees' awareness on achieving quality, as well as in companies with dissatisfied employees, if they are asked to actively execute the quality system although they are not adequately trained for it. The results of this research can help foreign researchers, which want to invest their capital in the Serbian companies. These results provide them with the insight in the companies' attitude toward the employees and their readiness to invest in human capital during training, improvement and development of awareness of achieving quality.

The researchers established a relation among the quality aspects, the levels of business operations and competitiveness. They also established the relation among the readiness to invest in knowledge, training and development from the aspect of quality. They also learned that companies, which raised employees' awareness on achieving quality, recognize the importance of quality as the factor of business operations improvement, while the companies without raised awareness often have dissatisfied employees. The explanations of the impact of knowledge and quality on the improvement of business relations and competitiveness provided guidelines to company managers so they can start acting in such a way to raise the level of awareness by including all the employees in attaining quality as a common goal. 
Cvjetković M.: Knowledge and quality as the factors of the business operations...

The objectives of the research are realized, and its results show statistically important relations among the level of business relations, knowledge improvement and quality aspects, and thus confirmed hypotheses.

The mentioned research results indicate that improvement of quality aspects in company goes along with the improvement of business operations and competitiveness. Effective management system in a company requires the adequate role of human resources. The employees are being trained and informed on necessary quality standards in companies in Serbia, but not to necessary extent and in proper way. Although the great share of companies stated they execute the training programs and raise employees' awareness on quality, the very essence and philosophy of quality is not fully accepted in Serbian companies. Quality must become personal responsibility of all employees. Managers in companies have to motivate workers to participate in teamwork in order to achieve quality and to carry out constant enhancements. The implementation of the quality system in company will not conduce to the improvement of business performances if there are no substantial changes in philosophy and method of business operations. Raising awareness on attaining quality in Serbian companies and changing the method and philosophy of business operations represent the connection between knowledge and quality as two substantial sources of competitive advantage and enhancement of business operations. Only with the adequate training and education on quality, by changing the former way of business operations and by accepting teamwork as the basis for quality achieving, Serbian companies will accomplish effective quality system, and thus provide higher level of business operations and competitiveness.

Taking into consideration the specific features of the transitional economies, such as Serbian economy covered by the research, the research results can help the economies that face the same problems. Moreover, they can be useful for further researches in this field and analyze the adequate aspects of professional training and development, which would have important effect on enhancement of quality aspects, as well as on coordination of learning process with the organization's objectives regarding quality improvement.

\section{Reference}

Akdere, M. (2009). The Role of Knowledge Management in Quality Management Practices: Achieving Performance Excellence in Organizations. Advances in Developing Human Resources, 11(3), 349-361. doi:10.1177/1523422309338575

Barber, K.D., Munive-Hernandez, J.E., \& Keane, J.P. (2006). Process-based knowledge management system for continuous improvement. International Journal of Quality \& Reliability Management, 23(8), 1002-1018. doi:10.1108/02656710610688185 
Cvjetković M.: Knowledge and quality as the factors of the business operations...

Bhat, K.S. (2010). Total Quality Management. Mumbai, IND: Himalaya Publishing House.

Bruce, S.H., \& Chen, S.K. (2007). The Impact of ISO 9000 on TQM and Business Performance. Journal of Business and Economic Studies, 13(2), 1-23.

Chiles, T.H., \& Choi, T.Y. (2000). Theorizing TQM: An Austrian and Evolutionary Economics Interpretation. Journal of Management Studies, 37(2), 185-212. doi:10.1111/1467-6486.00177

Chong, C.W., \& Chong, S.C. (2009). Knowledge management process effectiveness: measurement of preliminary knowledge management implementation. Knowledge Management Research and Practice, 7(2), 142-151. doi:10.1057/kmrp.2009.5

Choo, A.S., Linderman, K.W., \& Schroeder, R.G. (2007). Method and context perspectives on learning and knowledge creation in quality management. Journal of Operations Management, 25(4), 918-931. doi:10.1016/j.jom.2006.08.002

Choo, A.S., Linderman, K.W., \& Schroeder, R.G. (2007). Method and Psychological Effects on Learning Behaviors and Knowledge Creation in Quality Improvement Projects. Management Science, 53(3), 437-450. doi:10.1287/mnsc.1060.0635

Colurcio, M. (2009). TQM: a knowledge enabler. The TQM Journal, 21(3), 236-248. doi:10.1108/17542730910953013

Crossan, M.M., Lane, H.W., \& White, R.E. (1999). An organizational learning framework from intuition to institution.Academy of Management Review, 24(3), 522-537. doi:10.5465/amr.1999.2202135

Grant, R.M., \& Baden-Fuller, C. (2004). A Knowledge Accessing Theory of Strategic Alliances. Journal of Management Studies, 41(1), 61-84. doi:10.1111/j.14676486.2004.00421.x

Hung, R.Y., Lien, B.Y., Fang, S., \& McLean, G.N. (2010). Knowledge as a facilitator for enhancing innovation performance through total quality management. Total Quality Management \& Business Excellence, 21(4), 425-438. doi:10.1080/14783361003606795

Hung, R.Y.Y., Lien, B.Y.H., Yang, B., Wud, C.M., \& Kuo, Y.M. (2011). Impact of TQM and organizational learning on innovation performance in the high-tech industry. International Business Review, 20(2), 213-225. doi:10.1108/17542730910953013

-International Labour Organization. (2008). Skills for improved productivity, employment growth and development. In:International Labour Conference, 97th session.

Jayawarna, D., \& Holt, R. (2009). Knowledge and quality management: An R\&D perspective. Technovation, 29(11),

775-785. doi:10.1016/j.technovation.2009.04.004

Jennex, M.E., Smolnik, S., \& Croasdell, D.T. (2009). Towards a consensus knowledge management success definition.VINE: The Journal of Information and Knowledge Management Systems, 39(2), 174-188. doi:10.1108/03055720910988878

Jha, V.S., \& Joshi, H. (2007). Transforming knowledge assets for creating a learning organization - a conceptual approach for moving towards business excellence. International Journal for Business Research, 7(3), 134-142.

Johannessen, J., \& Olsen, B. (2003). Knowledge management and sustainable competitive advantages: The impact of dynamic contextual training. International 
Cvjetković M.: Knowledge and quality as the factors of the business operations...

Journal of Information Management, 23(4), 277-289. doi:10.1016/s02684012(03)00050-1

Kahin, B., \& Foray, D. (2006). Advancing Knowledge and the Knowledge Economy. Cambridge, MA, USA: MIT Press.

Katić, A., Ćosić, I., Anđelić, G., \& Raletić, S. (2012). Review of Competitiveness Indices that Use Knowledge as a Criterion.Acta Polytechnica Hungarica, 9(5), 25-45.

Lin, C., \& Wu, C. (2005). Managing knowledge contributed by ISO 9001:2000. International Journal of Quality \& Reliability Management, 22(9), 968-985. doi:10.1108/02656710510625239

Linderman, K., Schroeder, R.G., Zaheer, S., Liedtke, C., \& Choo, A.S. (2004). Integrating quality management practices with knowledge creation processes. Journal of Operations Management, 22(6), 589-607. doi:10.1016/j.jom.2004.07.001

Loke, S.P., Downe, A.G., Sambasivan, M., Kalid, K., \& Ooi, K.B. (2011). Integrating Total Quality Management and Knowledge Management to Supply Chain Learning: A Structural Approach. In: International Conference on Financial Management and Economics, 11. Singapore: Press.

Moffett, S., McAdam, R., \& Parkinson, S. (2003). An empirical analysis of knowledge management applications. Journal of Knowledge Management, 7(3), 6-26. doi:10.1108/13673270310485596

Molina, L.M., Lloréns-Montes, J., \& Ruiz-Moreno, A. (2007). Relationship between quality management practices and knowledge transfer. Journal of Operations Management, 25(3), 682-701. doi:10.1016/j.jom.2006.04.007

Porter, M.E. (2004). The Competitive Advantage of Nations. With a New Introduction. Ribière, V. M. \& Khorramshahgol, R. Integrating total quality management and knowledge management. Journal of Management Systems, 16(1), 39-54.

Ruiz-Moreno, A., Gracia-Morales, V., \& Lorens-Montes, J. (2005). Learning during the quality management process.Industrial Management \& Data Systems, 105(8), 1001-1021. doi:10.1108/02635570510624419

Ruzevicius, J.A.R., \& Sirvidaite, J. (2004). Motivation and Efficiency of Quality Management Systems Implementation: a Study of Lithuanian Organizations. Total Quality Management, 15(2), 173-190.

Saizarbitoria, I.H., Landín, G.A., \& Fa, M.C. (2006). The impact of quality management in European companies' performance. European Business Review, 18(2), 114131. doi:10.1108/09555340610651839

Schein, E. (2002). The anxiety of learning. Harvard Business Review, 81(1), 100-106.

Schwab, K., \& Porter, M. (2008). The global competitiveness report 2008-2009. World Economic Forum.

Schwab, K., \& Sala-i-Martín, X. (2014). The global competitiveness report 2014-2015. World Economic Forum.

Stewart, D., \& Waddell, D. (2008). Knowledge Management: The fundamental component for delivery of quality. Total Quality Management \& Business Excellence, 19(9), 987-996. doi:10.1080/14783360802227803

Zack, M., Mckeen, J., \& Singh, S. (2009). Knowledge management and organizational performance: an exploratory analysis. Journal of Knowledge Management, 13(6), 392-409. doi:10.1108/13673270910997088 
Cvjetković M.: Knowledge and quality as the factors of the business operations...

Stewart, D., \& Waddell, D. (2008). Knowledge Management: The fundamental component for delivery of quality. Total Quality Management, 19(9), 987-996. doi:10.1080/14783360802227803 